\title{
INFLUENCE OF SPECIMEN ORIENTATION ON DETERMINATION OF ELESTICITY IN STATIC BENDING
}

\author{
Felipe Hideyoshi Icimoto ${ }^{1, \wedge}$, Fabiane Salles Ferro ${ }^{1}$, Diego Henrique de Almeida ${ }^{1}$, \\ André Luís Cristoforo ${ }^{2}$, Francisco Antônio Rocco Lahr ${ }^{l}$
}

\begin{abstract}
Wood is a natural material and so many factors interfere in estimation of its physical and mechanical properties. Consequently variability in properties should be taken into account to rationalize its application. Longitudinal modulus of elasticity is one of the main mechanical properties of the material, and its value can be obtained via standardized tests. The aim of this study is to evaluate the influence of test conditions compatible with ABNT NBR 7190:1997 Code requirements to determine modulus of elasticity in static bending. For each of eight species, eight specimens were tested, all of them four times, with the sample oriented on each of its four faces related to load application. Data analysis was performed independently of species and their respective strength class, using hypothesis testing to evaluate influence of specimens' orientations to determination. It was concluded that specimen orientation is significant in determining modulus of elasticity in static bending according to ABNT NBR 7190:1997. This aspect can lead to a future normative review by the National Committee responsible by redaction of this Code. To represent natural variability of wood in specimens' volume by only one bending test, values of the modulus of elasticity should be lessened in $8 \%$.
\end{abstract}

Keywords: Modulus of elasticity, static bending test, stiffness.

\section{INTRODUCTION}

As a material of biological origin, wood has physical and mechanical properties for which variability is significantly influenced by different factors, from those related to microstructural anatomy to the sample position in the tree (Kollman and Côté 1968, Lahr 1983, Hein and Lima 2012).

Internal variations of wood can be expressed by differences between earlywood and latewood; between heartwood and sapwood; between regions in directions pith-bark and along of tree height (Nassur 2010).

Authors such as Haselein et al. (2000), Ballarin and Palma (2003), Evans et al. (2000) and for trees with 30, 37 and 40 years old, respectively, found that strength and stiffness properties in static bending are seriously affected by the juvenile wood presence. Properties in the region near to the bark (mature wood) were significantly higher than for wood located near the pith (juvenile wood).

Better to talk about the consequence of this for test standards - and how those test standards compare internationally.

Wood variability must be considered to determine the properties of a single specie or else to design a timber structure (Calil Junior et al. 2003).

\footnotetext{
Wood and Timber Structures (LaMEM) - Structural Engineering Department (SET) - School of Engineering of São Carlos (EESC) University of São Paulo (USP) -São Carlos, São Paulo, Brazil.

2 Mechanical Engineering Department (DEMEC) - Federal University of São João del Rei (UFSJ) - São João del Rei, Minas Gerais, Brazil.

- Corresponding author: icimoto@usp.br

Received: 30.05.2013 Accepted: 07.07.2014
} 
Several studies have led to quantify wood properties variability (Freitas 1978, Gonçalez et al. 2009, Gryc and Vavrčík 2009, Pimentel et al. 2008, Silva et al. 2005). Gonçalez et al. (2009) evaluated site influence on properties of Pinus caribea var. hondurensis. Trees were collected in two different locals, in Goias State, Brazil, far about $650 \mathrm{~km}$ each other. Static bending tests were performed according to code COPANT 30:1:006 (COPANT 1971): samples with nominal dimensions 2 x 2 x 30cm; moisture content $12 \%$. Results showed a difference about $30 \%$ in modulus of elasticity between wood from mentioned sites.

Lahr (1990) determined $18 \%$ as mean value to the coefficient of variation $(\mathrm{Cv})$ for $E$ values, based on results obtained by himself and on those presented by Hoyle (1973), Bolza and Kloot (1963) and Bendtsen (1974).

Knowledge of influence wood natural variability is crucial to define their applications to design, with safely, the components parts of a timber structure (Araújo 2007).

In Brazil, the physical and mechanical characterization of wood is conducted in accordance with Annex B of ABNT NBR 7190:1997: "Determination of wood properties for structural design". Results are essential for assignment of strength class of wood (Silva et al. 2012a).

According to Annex B of ABNT NBR 7190:1997, to determine modulus of elasticity $(E)$ in static bending, the displacement in mid-span point is measured in the same direction of applied load. This must be realized with increasing rate of $10 \mathrm{MPa} / \mathrm{min}$. Specimens are obtained from structural bars for which there is no imposition for the direction of growth rings in relation to faces. Samples must present ratio between span $(\mathrm{L})$ and height $(\mathrm{h}) \geq 21$. Above this, the influences of shear displacements are not significant in total deflection. In this condition, according with (Lahr 1983), simplified expression can be employed (Equation 1).

$$
E=\frac{P L^{3}}{48 v I}
$$

Where:

- $P$ is the applied force;

$-I$ is the momentum of inertia of cross section;

$-L$ is the span;

$-v$ is the deflection.

However, Brazilian Standard does not establish which orientation of the specimen, in relation to the growth rings, to take for the test. As wood is an anisotropic material, has three distinct planes, the radial, tangential and longitudinally, which provide different values for $E$ and for other physical and mechanical properties. Thus, depending on the orientation of the specimen chosen to perform the bending test, significant mistakes in the evaluation of serviceability limit states structural elements in static bending can be detected.

European (EN 408: 1995) and Chilean (NCh 1198:2006) normative documents do not refer to specimens orientation in static bending tests, as well as the Brazilian Standard.

ASTM D143: 2009, for example, adopts sampling such that it is possible to orient samples to perform tests in such a way as to obtain minimum $E$ value.

In this context, the aim of this study was to determine influence of test conditions required by ABNT NBR 7190:1997 to determine modulus of elasticity in static bending. 


\section{MATERIALS AND METHODS}

Research was developed in the Wood and Timber Structures Laboratory (LaMEM), Department of Structural Engineering (SET), School of Engineering of São Carlos (EESC), University of São Paulo (USP). For this study eight wood species were used, considering the strength classes adopted by Brazilian Standard ABNT NBR 7190:1997 (Table 1).

According to Brazilian Standard ABNT NBR7190:1997 clear specimens presented 12\% moisture content, nominal cross section $5 \mathrm{~cm} \times 5 \mathrm{~cm} ; 105 \mathrm{~cm}$ span $(L)$.

Table 1. Strength classes and specific gravity of used species.

\begin{tabular}{cccc}
\hline Species & Scientific name & Strength classes & $\begin{array}{c}\text { Density measured } \\
\left(\mathrm{kg} / \mathrm{m}^{3}\right)\end{array}$ \\
\hline Cambará rosa & Erisma sp. & C20 & 750 \\
Eucalipto grandis & Eucalyptus grandis & C30 & 650 \\
Pinus elliottii & Pinus elliottii & C30 & 560 \\
Cupiúba & Goupia glabra & C40 & 800 \\
Eucalipto citriodora & Corymbia citriodora & C40 & 990 \\
Ipê & Tabebuia sp. & C50 & 960 \\
Jatobá & Hymenaea stilbocarpa & C60 & 940 \\
Angico rosa & Anadenanthera falcata & C60 & 920 \\
\hline
\end{tabular}

To determine the modulus of elasticity, measurement of deflections were performed on four faces of each specimen (four tests). Faces were named 1, 2, 3 and 4. The specimens were prepared without guidance regarding to the growth rings, according to ABNT NBR 7190:1997. Tests were performed in a universal testing machine, with capacity $250 \mathrm{kN}$.

According to ABNT NBR 7190:1997, the ratio L/200 (L is the span) establishes the maximum displacement in pieces submitted to static bending, supported in its extremities. In this situation, linear elastic deformation is ensured. Using a $105 \mathrm{~cm}$ span, $\mathrm{L} / 200 \approx 5 \mathrm{~mm}\left(\mathrm{v}_{5}\right)$ for maximum displacement, considered close to $50 \%$ for the force $\left(\mathrm{F}_{\mathrm{m}, 5}\right)$. However, displacement of $1 \mathrm{~mm}\left(\mathrm{v}_{1}\right)$ was considered representing $10 \%$ for the force $\left(\mathrm{F}_{\mathrm{m}, 1}\right)$.

Displacement of the opposite face related to applied load was measured using dial gage, sensitivity $0,01 \mathrm{~mm}$. Top dial gage shows the load applied and the bottom dial gage measures specimen's displacement. Figure 1 shows Jatobá wood specimen in static bending test.

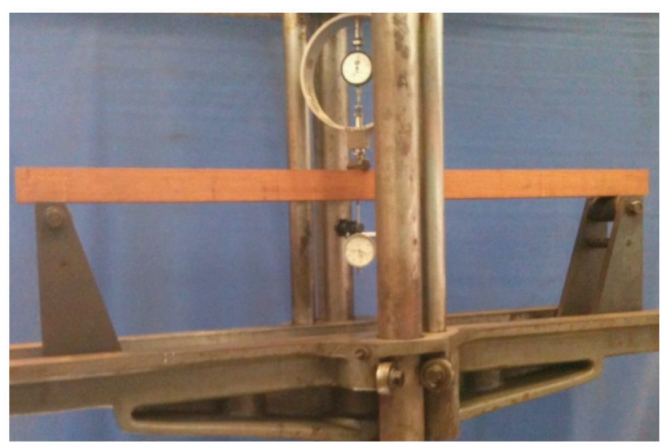

Figure 1. Bending test in Hymenaea stilbocarpa wood specimen. 
$E$ in bending was determined using equation 2.

$$
E=\frac{\left(F_{m, 5}-F_{m, 1}\right) L^{3}}{4\left(v_{5}-v_{1}\right) b h^{3}}
$$

Where:

- $F_{m, l}(\mathrm{~N})$ is the load corresponding to $1 \mathrm{~mm}$ deflection $\left(v_{l}\right)$;

$-F_{m, 5}(\mathrm{~N})$ is the load corresponding to $5 \mathrm{~mm}$ deflection $\left(v_{5}\right)$;

$-L=105 \mathrm{~cm}$ is the span (mm);

$-b$ is the width of specimen cross section $(\mathrm{mm})$;

$-h$ is the height of specimen cross section ( $\mathrm{mm})$.

Each specimen was tested four times (small displacements were adopted to ensure linearity and geometry wood). To check influence of load orientation in $E$ calculation, for each specimens ratio between lower (denoted A) and highest (denoted D) $E$ values for each specimen were determined (nondimensional variable). Intermediate ratios conducted to faces called B and C. Thus, it was possible to perform data analysis independent of species and their respective strength classes. Minitab software ${ }^{\circledR}$ was used to perform the hypothesis test to evaluate the mentioned influence.

If observed non-equivalence between modulus of elasticity $(\mathrm{A} / \mathrm{D} \neq 1)$, least square method (Equation 3 ) was used determined the optimal coefficient based on minimum residue criterion (Christoforo et al. 2012), providing $A / D$ ratio $=\gamma$ Unit.

$$
f(\gamma)=\frac{1}{2} \sum(\text { A / D ratio }-\gamma \text { Unit })^{2}
$$

Where:

$-f(\gamma)$ is least square method function;

- $\gamma$ is optimum coefficient;

- $A / D$ ratio is vector consisting of values less than 1 (ratio between the lowest values and the greater values of $E$ found by specimen);

- Unit is vector components equal to 1 (expected value of ratio between the modulus of elasticity). 


\section{RESULTS AND DISCUSSION}

Table 2 presents results of modulus of elasticity in static bending, related to specimen positions: sample mean $\left(\mathrm{x}_{\mathrm{m}}\right)$, Min and Max the smallest and largest values found for $E$, respectively, for all samples.

Table 2. Mean values of E obtained for the eight species evaluated.

\begin{tabular}{|c|c|c|c|c|c|}
\hline \multirow[b]{2}{*}{ Species } & & \multicolumn{4}{|c|}{$E(\mathrm{MPa})$} \\
\hline & & $\begin{array}{c}\text { Orientation } \\
\text { A }\end{array}$ & $\begin{array}{l}\text { Orientation } \\
\text { B }\end{array}$ & $\begin{array}{l}\text { Orientation } \\
\text { C }\end{array}$ & $\begin{array}{c}\text { Orientation } \\
\text { D }\end{array}$ \\
\hline \multirow{3}{*}{$\begin{array}{c}\text { Anadenanthera } \\
\text { falcata }\end{array}$} & $\mathrm{x}_{\mathrm{m}}$ & 21627 & 21878 & 22392 & 22574 \\
\hline & Min & 18496 & 18540 & 18540 & 18629 \\
\hline & Max & 24808 & 25072 & 26657 & 26702 \\
\hline \multirow{3}{*}{ Erisma $\mathrm{sp}$} & $\mathrm{x}_{\mathrm{m}}$ & 11857 & 12061 & 12294 & 12390 \\
\hline & Min & 9814 & 10061 & 10209 & 10258 \\
\hline & $\operatorname{Max}$ & 13430 & 13899 & 14040 & 14087 \\
\hline \multirow{3}{*}{ Goupia glabra } & $\mathrm{x}_{\mathrm{m}}$ & 12992 & 13164 & 13388 & 13717 \\
\hline & Min & 10791 & 11071 & 11480 & 14834 \\
\hline & Max & 14834 & 15796 & 15796 & 15796 \\
\hline \multirow{3}{*}{$\begin{array}{l}\text { Corymbia } \\
\text { citriodora }\end{array}$} & $\mathrm{x}_{\mathrm{m}}$ & 14842 & 15092 & 15326 & 15522 \\
\hline & Min & 11443 & 12047 & 12423 & 12797 \\
\hline & Max & 18134 & 18183 & 18330 & 18527 \\
\hline \multirow{3}{*}{$\begin{array}{l}\text { Eucalyptus } \\
\text { grandis }\end{array}$} & $\mathrm{x}_{\mathrm{m}}$ & 11345 & 11540 & 11758 & 11973 \\
\hline & Min & 9632 & 9826 & 10077 & 10302 \\
\hline & Max & 13477 & 13620 & 14193 & 14207 \\
\hline \multirow{3}{*}{ Tabebuia sp. } & $\mathrm{x}_{\mathrm{m}}$ & 17565 & 17961 & 18122 & 18318 \\
\hline & Min & 15620 & 16262 & 16408 & 16480 \\
\hline & Max & 18932 & 19526 & 19604 & 20006 \\
\hline \multirow{3}{*}{$\begin{array}{l}\text { Hymenaea } \\
\text { stilbocarpa }\end{array}$} & $\mathrm{x}_{\mathrm{m}}$ & 20764 & 20897 & 21140 & 21575 \\
\hline & Min & 19668 & 19668 & 19947 & 20226 \\
\hline & Max & 22869 & 22869 & 22869 & 23104 \\
\hline \multirow{3}{*}{ Pinus elliottii } & $\mathrm{x}_{\mathrm{m}}$ & 12307 & 12474 & 13058 & 13130 \\
\hline & Min & 8033 & 8588 & 8674 & 8759 \\
\hline & Max & 14632 & 14632 & 15355 & 15489 \\
\hline
\end{tabular}

According to table 2, the highest variation among values of modulus of elasticity in static bending (ration of D/A for each specie) was found to Pinus elliottii $(6,7 \%)$, while the lowest variation was obtained by Hymenaea stilbocarpa (3,9\%).

This result is consistent with those obtained by Silva et al. (2012b), which assessed the influence of the face choice to determine modulus of elasticity in static bending for three wood species, and found variations up to $5,2 \%$ between the $E$ of opposite faces analyzed.

Table 3 presents results of ratios between the smallest $\left(E_{A}\right)$ and larger $\left(E_{D}\right)$ values of modulus of elasticity obtained by specimens, $\mathrm{Sd}$ is the standard deviation and $\mathrm{Cv}$ the coefficient of variation. 
Table 3. Results of the ratio between the modulus of elasticity between $E_{A}$ and $E_{D}$.

\begin{tabular}{cc}
\hline Statistic symbols & $E_{\mathrm{A}} / E_{\mathrm{D}}$ \\
\hline $\mathrm{x}_{\mathrm{m}}$ & 0,953 \\
$\mathrm{Sd}$ & 0,026 \\
$\mathrm{CV}(\%)$ & 3 \\
$\mathrm{Min}$ & 0,892 \\
Max & 0,993 \\
\hline
\end{tabular}

Figure 2 shows results Anderson-Darling normality test on ratio between $E$. Test significance level $(\alpha)$ is $5 \%$, consisting of normal data for the null hypothesis $\left(\mathrm{H}_{0}\right)$ and non-normality of the data to the alternative hypothesis $\left(\mathrm{H}_{1}\right)$. Thus, $\mathrm{P}$-value of the test superior than the significance level implies in accepting $\mathrm{H}_{0}$, rejecting it otherwise.

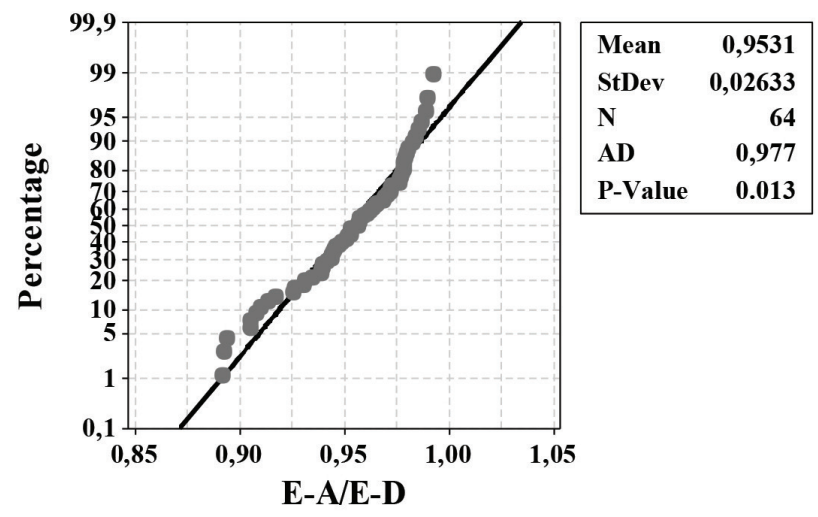

Figure 2. Normality test results of for the ratio between the modulus of elasticity.

As P-value obtained (Figure 2) is less than 0,05 (5\%), distribution of ratio between modulus of elasticity appears not to be the normal. It is noteworthy that data normality is required for hypothesis testing. Therefore, Johnson transformation (Figure 3), presented by Equation 4, was applied, where X is ratio between modulus of elasticity and $\mathrm{Y}$ value found from the transformation. 


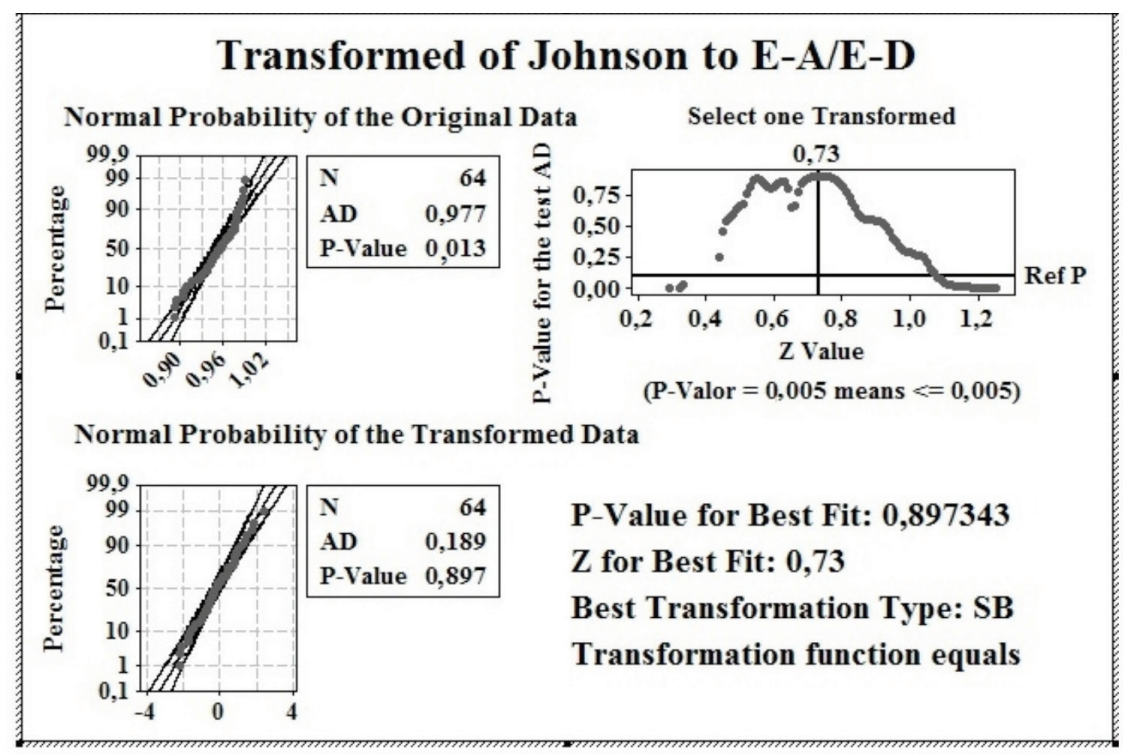

Figure 3. Johnson transformation of ratio between modulus of elasticity.

$$
Y=-1,10295+1,02554 \log \left(\frac{X-0,855648}{1,097091-X}\right)
$$

Figure 4 shows results of Anderson-Darling normality test, on transformed data. P-value obtained is higher than $5 \%$, validating the use of hypothesis testing.

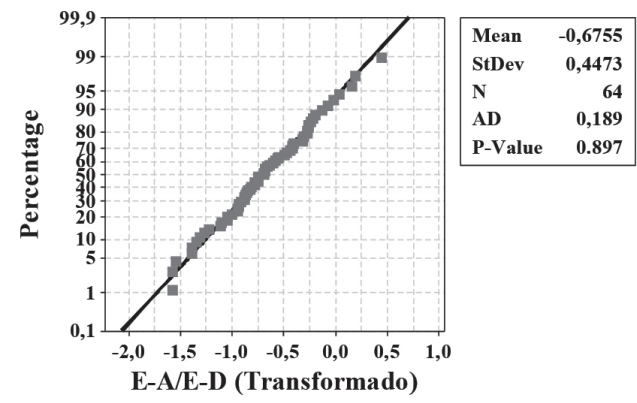

Figure 4. Normality test results for ratio between modulus of elasticity: transformed data.

The unit, expected value of the ratio between modulus of elasticity on condition that equivalent $\left(E_{A} /\right.$ $E_{D} \equiv 1$ ), transformed by Equation 3 becomes $-0,956$, value used in the formulation of hypothesis testing. Table 4 shows the hypothesis testing results to verify their respective representation on the set with the sixty-four values of the ratio between the bending modulus of elasticity. Hypothesis test was evaluated for the significance level of $5 \%$, using the mean equal to $-0,956$ as null hypothesis $\left(H_{0}: \mu=-0,956\right)$ and the mean different to $-0,956$ as alternative hypothesis $\left(H_{1}: \mu \neq-0,956\right)$. As the $\mathrm{P}$-value found is less than the significance level $(0,05)$, reject the null hypothesis, implying significant is the choice of the specimen's orientation to determine the bending modulus of elasticity. 
Table 4. Hypothesis testing results.

\begin{tabular}{ccc}
\hline \multirow{2}{*}{ Relation: $E_{\mathrm{A}} / E_{\mathrm{D}}$} & Confidence Interval & P-valor \\
\cline { 2 - 3 } & $(-0,787 ;-0,564)$ & 0 \\
\hline
\end{tabular}

Coefficient $\gamma$ obtained via least squares method (A/D ratio $=\gamma$ Unit) was equal to 0,92 , resulting in the possibility of obtaining a minimum modulus of elasticity up to $8 \%$ different from that obtained when testing the specimen only in one orientation.

\section{CONCLUSIONS}

Results obtained indicated that the choice of face is significant to obtain the modulus of elasticity in static bending modulus. However, Brazilian Standard ABNT NBR 7190:1997 and others guidelines, used in countries with tradition in building timber structures, have not discussed this influence and it's possible that some expressive consequences are not taking in account.

Therefore, to natural wood variability present in the specimen volume be represented by only one static bending test, values of modulus of elasticity must be corrected (lessened) by $8 \%$, however, if tests would performed on all four sides is recommended to use mean value of $E$. This very significant reduction, in practical terms, would make an expressive difference in timber structures design.

This paper aims to provide this information to better consideration by Standard Committee and any reductions for $E$ will be (or not) adopted depending on assumed general guidelines for Code redaction.

\section{ACKNOWLEDGMENT}

Authors thank Wood and Timber Structures Laboratory (LaMEM), in Structural Engineering Department (SET), School of Engineering of São Carlos (EESC), University of São Paulo (USP), and for financial support by CAPES (Coordination for Improvement of Higher Educational Personnel) and $\mathrm{CNPq}$ (National Counsel of Technological and Scientific Development).

\section{REFERENCES}

Araújo, H. J. B. 2007. Relações funcionais entre propriedades físicas e mecânicas de madeiras tropicais brasileiras. Florestas 37 (3): 399-416.

American Society for Testing And Materials. ASTM. 2009. ASTM D143: Standard test methods for small clear specimens of timber. West Conshohocken. USA

Associação Brasileira De Normas Técnicas. ABNT. 1997. Projetos de estruturas de madeiras. ABNT NBR 7190:1997, Rio de Janeiro. Brasil.

Ballarin, A.W.; Palma, H.A.L. 2003. Propriedades de resistência e rigidez da madeira juvenil e adulta de Pinus taeda L. Revista Árvore 27 (3): 371-380. 
Bendtsen, B.A. 1974. Specific gravity and mechanical properties of black, red, and white spruce and balsam fir. Forest Products Laboratory, Madison.

Bolza, E.; Kloot, H.H. 1963. The mechanical properties of 174 Australian timbers. Commowealth Scientific and Industrial Research Organization. Australia.

Calil Junior, C.; Lahr, F. A. R.; Dias, A. A. 2003. Dimensionamento de elementos estruturais de madeira. Manole. Brazil, Barueri. 152p.

Christoforo, A.L.; Rocco, F. A. L.; Morales, E.A. M.; Panzera, T.H.; Borges, P.H. 2012. Numerical evaluation of longitudinal modulus of elasticity of Eucalyptus grandis timber beams. International Journal of Agriculture and Forestry (2): 166-170.

Comisión Panamericana de Normas Técnicas. COPANT. 1971. Maderas: método de determinación del peso especifico aparente: COPANT 30:1:004. Caracas, Venezuela.

Evans, J.W.; Senft, J.F.; Green, D.W. 2000. Juvenile wood effect in red alder: analysis of physical and mechanical data to delineate juvenile and mature wood zones. Forest Products Journal 50 (7): 75-87.

European Commitee For Standardzation. 1995. Timber structures. Structural timber and glued laminated timber. Determination of some physical and mechanical properties. EN 408: 1995. Brussels, Belgium.

Freitas, A.R. 1978. Probabilistic approach in the design of wood structures in Brazil based on the variability of 23 species. Master's Dissertation, Virginia Polytechnic Institute, Virginia, United States of America.

Gonçalez, J.C.; Vieira, F.S.; Camargos, J.A.A.; Zerbini, N.J. 2009. Influence of site on properties of wood of Pinus caribaea var. hondurensis. Cerne 15 (2): 251-255

Gryc, V.; Vavrčík, H. 2009.Variability of spruce (Picea abies [L.] Karst.) compression strength with present reaction wood. Journal of Forest Science 55 (9): 415-422.

Haselein, C.R.; Cechin, E.; Santini, E.J.; Gatto, D.A. 2000. Características estruturais da madeira de Pinus elliottii Engelm. aos 30 anos de idade. Ciência Florestal 2 (10): 135-144.

Hein, P.R.G.; Lima, J.T. 2012. Relationships between microfibril angle, modulus of elasticity and compressive strength in Eucalyptus wood. Maderas-Cienc Tecnol 14 (3): 267-274.

Hellmeister, J.C. 1973. Sobre a determinação das características físicas da madeira. DoctoralThesis, Universidade de São Paulo, São Carlos, Brazil.

Hoyle Junior, R.J. 1973. Wood technology in the design of structures. Mountain Press, Montana.

Instituto Nacional de Normalizacion. INN. 2006. Madera. Construcciones en madera. Cálculo. NCh1198 Of: 2006, Santiago. Chile.

Kollmann, F.F.P.; Côté Jr, W.A. 1968. Principles of wood science and technology. Springer-Verlag. Berlin, Germany. 592p. 
Lahr, F.A.R. 1983. Sobre a determinação de propriedades de elasticidade da madeira. Doctoral Thesis, Universidade de São Paulo, São Carlos, Brazil.

Lahr, F.A.R. 1990. Considerações a respeito da variabilidade de propriedades de resistência e de elasticidade da madeira. Thesis, Universidade de São Paulo, São Carlos, Brazil.

Matthew, T.J.E. 1961. Bases para o dimensionamento de estruturas de madeira. LNEC. Lisboa, Portugal. 308p.

Nassur, O. A. C. 2010. Variabilidade das propriedades tecnológicas da madeira Toonaciliata M. Roem com dezoito anos de idade. Master's Dissertation, Universidade Federal de Lavras, Lavras, Brazil.

Pimentel M. M.; Selegato P. A. M.; Garcia J. N.; Lima I. L. 2008. Variação de propriedades da madeira de Tectona grandis Linn. F. (Teca) em função do espaçamento e da posição radial na tora. Instituto Florestal 1 (36): 19-24.

Silva, D.A.L.; Lahr, F.A.R.; Faria, O.B.; Chahud, E. 2012a. Influence of wood moisture content on modulus of elasticity on compression parallel to grain. Materials Research 15 (2): 300-304.

Silva J.C.; Matos J.L.M.; Oliveira J.T.S.; Evangelista V.W. 2005. Influência da idade e da posição radial na flexão estática da madeira de Eucalyptus grandis hill ex. maiden. Revista Árvore 29 (5): 795-799.

Silva, D.A.L.; Bertolini, M.S.; Souza, A.M.; Calil Neto, C.; Lahr, F.A.R. 2012b. Influência da idade na resistência à flexão e compressão paralela da madeira de Paricá. In: Encontro Brasileiro em Madeira e em Estruturas de Madeira, 2012, Vitória, Brazil. Procedings UFES, CD-ROM. 